\title{
Pilomatrical carcinosarcoma in the very elderly: A case report
}

\author{
KAZUKI SUEMUNE ${ }^{1}$, YASUSHI ADACHI ${ }^{1-3}$, MASAYUKI TAKAGI ${ }^{4}$, \\ TOSHIHARU TOKURIKI ${ }^{5}$, HAJIME AKIYAMA ${ }^{6}$ and SUSUMU IKEHARA ${ }^{7 *}$
}

\begin{abstract}
${ }^{1}$ Department of Diagnostic Pathology, Toyooka Hospital, Toyooka, Hyogo 668-8501; ${ }^{2}$ Department of Pediatrics, Kansai Medical University, Hirakata, Osaka 573-1010; ${ }^{3}$ Medical Department, Keishinkai Ayabe Sakura Home, Ayabe, Kyoto 623-0045; ${ }^{4}$ Department of Laboratory Medicine, Shizuoka Medical Center, Shimizu-Cho, Shizuoka 411-8611; Departments of ${ }^{5}$ Plastic and Reconstructive Surgery and ${ }^{6}$ Dermatology, Toyooka Hospital, Toyooka, Hyogo 668-8501; ${ }^{7}$ Department of Stem Cell Disorders, Kansai Medical University, Hirakata, Osaka 573-1010, Japan
\end{abstract}

Received December 17, 2020; Accepted July 21, 2021

DOI: $10.3892 / \operatorname{mco} .2021 .2426$

\begin{abstract}
Pilomatrical carcinosarcomas are very rare tumors. To the best of our knowledge, only nine cases diagnosed with pilomatrical carcinosarcomas have been reported. The present study reported on a case of pilomatrical carcinosarcoma in the posterior part of the left auricle of a 100-year-old male patient. The tumor histologically comprised the following two components: Pilomatrical carcinoma and undifferentiated spindle cell sarcoma. The pilomatrical carcinoma comprised atypical basaloid cells and shadow cells. The basaloid cells had basophilic cytoplasm, clear nucleoli and deeply stained nuclear chromatin. The undifferentiated spindle cell sarcoma comprised atypical spindle cells. Both components contained numerous mitotic cells. The boundary area between the carcinoma and sarcoma smoothly transitioned into each other. The carcinoma cells and a portion of the sarcoma cells were positive for $\beta$-catenin in the cytoplasm with or without the nuclei. These results suggested that the two components developed from the same origin.
\end{abstract}

\section{Introduction}

Among pilomatrical tumors, pilomatricoma (calcifying epithelioma) is a well-known benign tumor type, whereas pilomatrical carcinoma and pilomatrical carcinosarcoma are considered malignant counterparts of pilomatricoma. Both of these malignant tumor types are rare. In particular, pilomatrical carcinosarcoma is a very rare tumor and, to the best of

Correspondence to: Dr Yasushi Adachi, Department of Pediatrics, Kansai Medical University, 2-5-1 Shinmachi, Hirakata, Osaka 573-1010, Japan

E-mail: adachiya250@gmail.com

"Deceased

Key words: pilomatrical carcinosarcoma, super-elderly, human, skin our knowledge, it has been reported in only nine patients thus far. Pilomatricoma is usually observed in young individuals and is predominantly occurs in females. By contrast, pilomatrical carcinoma is primarily observed in middle-elderly males $(1,2)$. It usually occurs between the 5 th and 7 th decade of life (2). It has been reported that the origin of pilomatrical carcinoma may be a malignant transformation of pilomatricoma or it may be a de novo development altogether $(1,3)$. Furthermore, pilomatrical tumors have been associated with mutations in exon 3 of the $\beta$-catenin gene (CTNNB1) and the mutation is reflected in the expression of $\beta$-catenin in the tumors $(4,5)$.

The origin of pilomatrical carcinosarcoma has remained largely elusive. Histologically, it consists of pilomatrical epithelial and sarcomatous lesions. The same genetic abnormalities and abnormal expression of $\beta$-catenin are observed in both epithelial and sarcomatous lesions of pilomatrical carcinosarcoma, suggesting that both lesion types are derived from the same precursor or that the sarcomatous lesion transdifferentiates from the epithelial lesion (5-9). Certain cases of pilomatrical carcinosarcoma have been observed to exhibit slow growth in the early stages and have had a long observation period prior to resection, which suggests malignant transformation from a benign tumor (7-10).

For pilomatrical carcinosarcoma to be diagnosed, it is necessary to confirm both the pilomatrical epithelial lesion (pilomaricoma or pilomatrical carcinoma) and sarcomatous lesion in a histological examination. Immunohistochemically, the epithelial lesion expresses cy tokeratin and it does not express vimentin, while the mesenchymal lesion expresses vimentin and the sarcomatous lesion or a part of it expresses cytokeratin in certain cases. It has been reported that both epithelial and sarcomatous lesions abnormally express $\beta$-catenin and express P53 (5-9). Surgical resection of the tumor has been performed as a therapy for both types of pilomatrical carcinosarcoma.

The present study reported on a case of pilomatrical carcinosarcoma observed in a 100-old-year male. The carcinoma component of the tumor was pilomatrical carcinoma, whereas the sarcoma component was undifferentiated spindle cell sarcoma, with a smooth transition between the two components. 


\section{Case report}

A 100-year-old male patient consulted a general practitioner due to a $45 \times 30 \mathrm{~mm}$ tumor in the posterior part of his left auricle. It was observed to be a cutaneous tumor. The surface of the lesion was ulcerated with bleeding (Fig. 1). The size of the ulcer was $29 \times 23 \mathrm{~mm}$. As underlying conditions, the patient had cryptogenic organizing pneumonia, chronic kidney disease and hypothyroidism. The tumor was noted to be $\sim 1 \mathrm{~cm}$ in diameter in the posterior part of his left auricle $\sim 1$ year prior to the consultation. The tumor rapidly developed and erosion with bleeding was observed on the surface of the tumor. The patient was referred to the Department of Dermatology of Toyooka Hospital (Toyooka, Japan) in November 2019 and a needle biopsy of the tumor was performed. Histological examination of the biopsy sample suggested that the tumor was malignant and fibrosarcoma was suspected. Therefore, the tumor was resected by a plastic and reconstructive surgeon.

The size of the resected tumor was $45 \times 30 \times 16 \mathrm{~mm}$ with exophytic growth. Histological examination of the tumor revealed that the tumor had been primarily located in the dermis while infiltrating the deeper portion of the dermis and that the tumor comprised two components (Fig. 2). The first component presented as a pilomatricoma-like area (right side of Fig. 2A and D) and the second consisted of spindle cells (left side of Fig. 2A and B). A transition area was present between these two components (Fig. 2A and C). The pilomatricoma-like area was comprised of basophilic atypical basaloid cells, shadow cells and multinuclear giant cells with necrosis and calcification (Figs. 2D and 3A-C). The basaloid cells had basophilic cytoplasm, clear nucleoli and deeply stained nuclear chromatin. The spindle cells in the second component exhibited plump atypical nuclei (Figs. 2B and 3B and D). Necrosis and fibrosis were also observed in the spindle cell area (Fig. 3D). In the boundary area, the two components gradually transitioned into each other (Figs. 2C and 3B). Both components contained numerous mitotic cells. The ratio of epithelial lesion to the spindle cell lesion was 2:3. There was no vascular invasion and the surgical margin was negative.

Immunohistochemistry was also performed using the fully automated immunohistochemical stainer BOND-III (Leica Biosystems), which uses the antigen retrieval reagent Bond epitope retrieval ( $\mathrm{pH} 9$; Leica Biosystems) and a staining kit containing second antibodies (BOND Polymer Refine Detection; cat. no. DS9800; Leica Biosystems). The following prediluted primary antibodies were used: Anti-Ki-67 (cat. no. IS629), P53 (cat. no. IS616), cytokeratin (CK) AE1/AE3 (cat. no. IS053), CK 5/6 (cat. no. M7273), epithelial membrane antigen (EMA) (cat. no. IS625), vimentin (cat. no. IS630), CD31 (cat. no. IS610), CD34 (cat. no. IS632), CD56 (cat. no. IS628), desmin (cat. no. IS606) and $\alpha$-smooth muscle actin ( $\alpha$-SMA) (cat. no. IS611) antibodies (Agilent Technologies, Inc.); anti-factor XIIIa antibody (cat. no. PA0449; Leica Biosystems); and anti-S100 protein (cat. no. 422091), synaptophysin (cat. no. 43831) and chromogranin A (cat. no. 412751) antibodies (Nichrei Biosciences, Inc.). Immunohistochemically, both the components were negative for CD34, CD56, chromogranin A, synaptophysin, S100, desmin and factor XIIIa and positive for P53. Staining

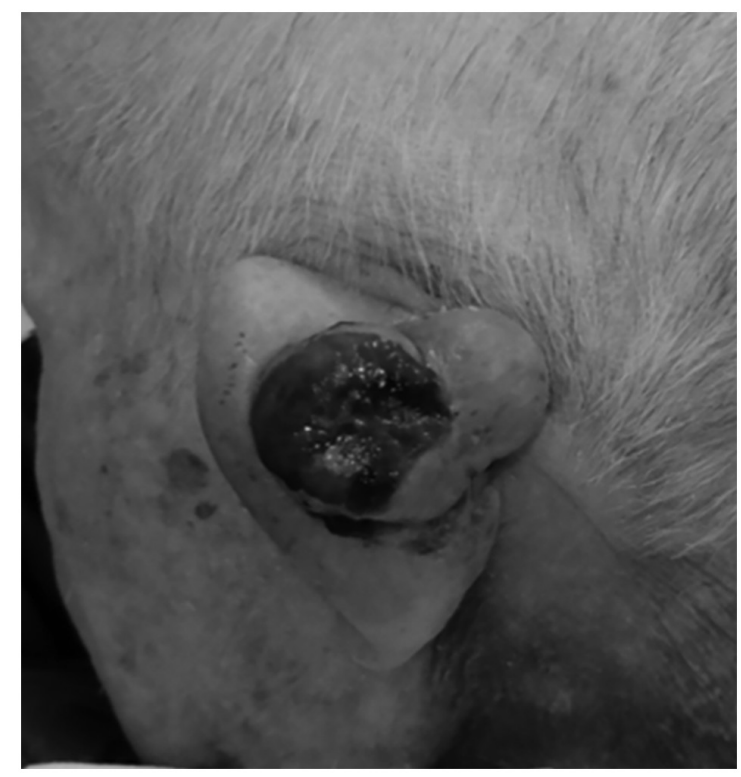

Figure 1. Macroscopic observation. A tumor with a hemorrhagic ulcer was observed in the posterior part of the left auricle. The size of the tumor was $45 \times 30 \mathrm{~mm}$

for CK AE1/AE3 was positive in the basaloid cell component and weakly-moderately positive in a small number of scattered cells in the spindle cell component (Fig. 4A). Furthermore, staining for CK 5/6, P40 and EMA was positive in the basaloid cells, but negative in the spindle cell component (results not shown). Staining for CK AE1/AE3 and CK 5/6 was positive in the cytoplasm and staining for EMA was positive on the cell membrane with or without the cytoplasm. The nuclei were positive for P40. Staining for vimentin was positive in the cytoplasm of the spindle cell component and in a small part of the basaloid cells (Fig. 4B). Most of the basaloid cells were negative for vimentin. CD31 was partially weakly-moderately positive in the cytoplasm and cell membrane of the spindle cell component and negative in the basaloid cells (Fig. 4C). Staining for $\alpha$-SMA was partially weakly-moderately positive in the cytoplasm of the spindle cell component and negative in the basaloid cell component (Fig. 4D). Furthermore, staining for $\beta$-catenin was clearly positive in the nuclei and cytoplasm of the basaloid cells (Fig. 4E). In the spindle cell area, $\beta$-catenin expression was lower than that in the basaloid cell area, but part of the spindle cells expressed $\beta$-catenin in the cytoplasm (Fig. 4E). Staining for P53 was positive in the nuclei of the tumor and $91.3 \%$ of the tumor cells in the carcinoma area were positive for P53, whereas $51.0 \%$ of the tumor cells in the sarcoma area were positive for P53 (Fig. 4F). The Ki-67 labeling index was $36.4 \%$ in the hot-spot of the basaloid cells (Fig. 4G). These results suggested that the pilomatricoma-like area may be considered as a pilomatrical carcinoma. The Ki-67 labeling index in the hot-spot of the spindle cell component was $35.8 \%$, suggesting that the tumor was a pilomatrical carcinosarcoma (Fig. 4G).

The patient suddenly died 75 days after the resection of the tumor, possibly due to acute cardiac failure. After the surgery, the patient did not exhibit any symptoms suggesting tumor recurrence and/or metastasis. The patients came to the hospital 6 times to receive follow-up examinations after the surgery. 


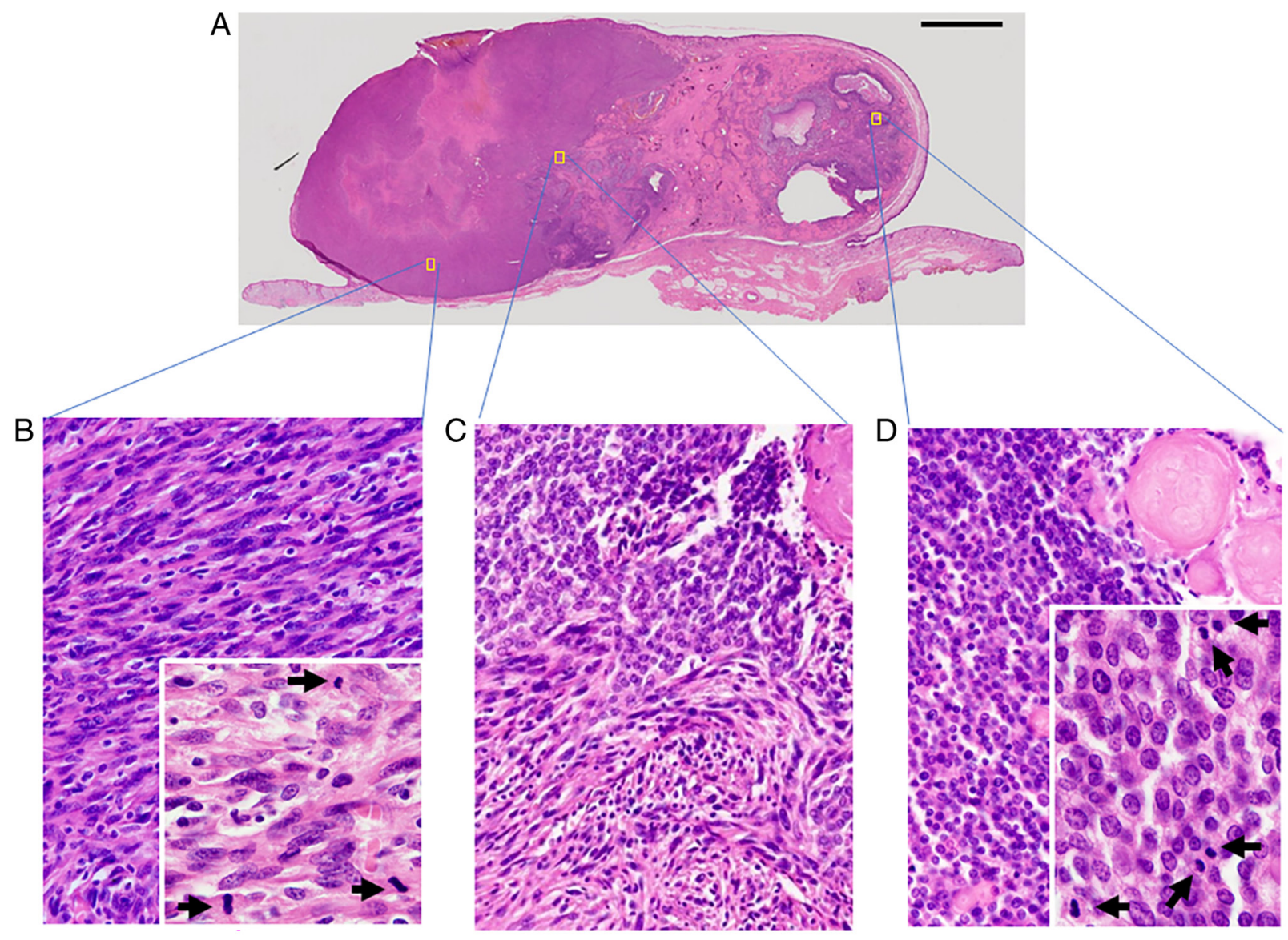

Figure 2. Histological examination of the tumor with hematoxylin and eosin staining. (A) Loupe image of the whole tumor (scale bar, $5 \mathrm{~mm}$ ). (B) Sarcomatous component. (C) Site of transition. (D) Carcinomatous component. The original magnifications of the objective lens were x40 in B-D and x100 in the insets of B and D. Arrows in the insets indicate mitotic tumor cells.
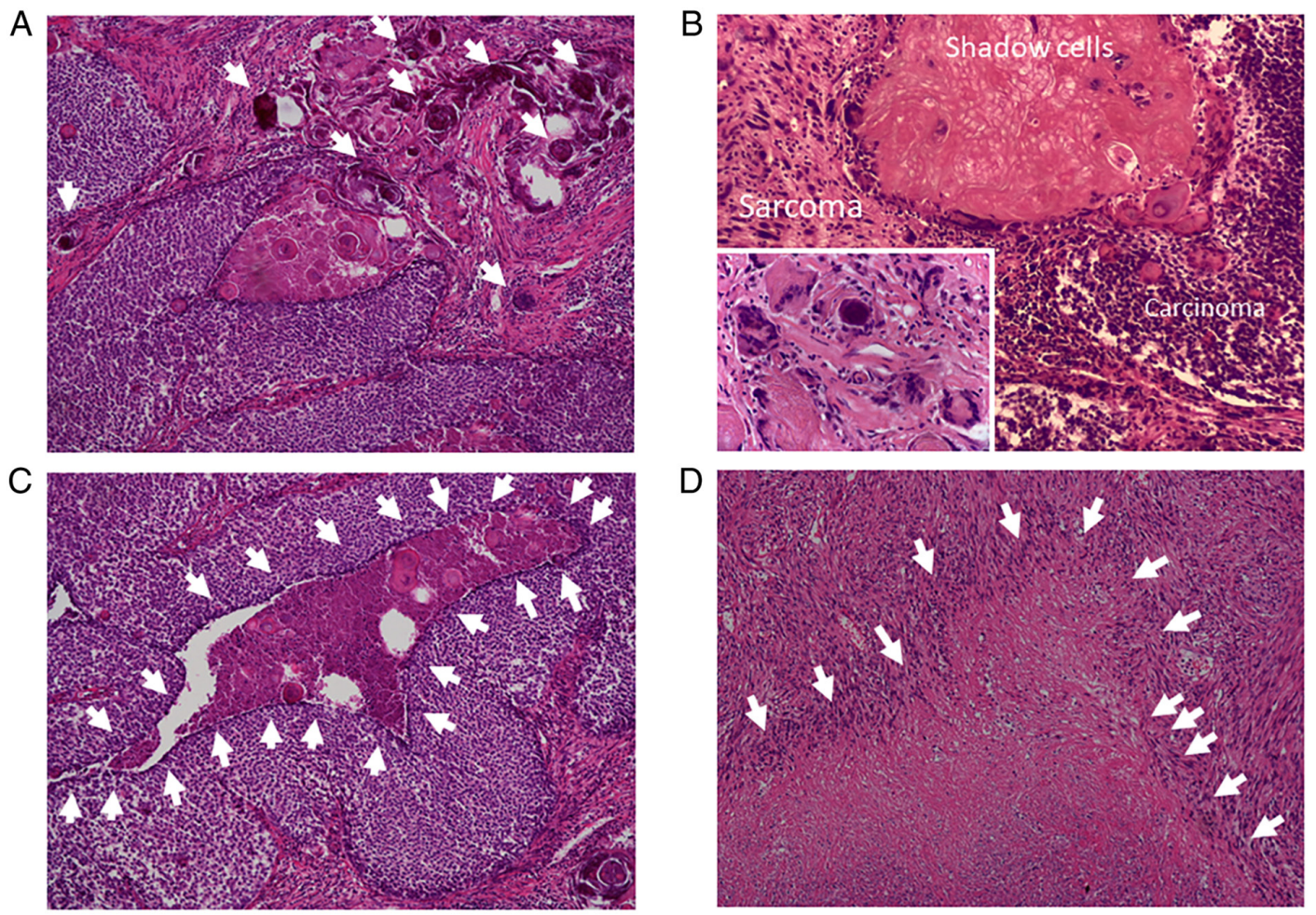

Figure 3. Photomicrographs of calcification, shadow cells, giant cells and necrotic areas in the tumor. (A) Small calcification foci, as indicated by arrows, are visible in the pilomatrical carcinoma area. (B) An area containing carcinoma, sarcoma and shadow cells is presented. In the inset, multinuclear giant cells are visible. Necrotic areas are indicated by arrows in (C) carcinoma and (D) sarcoma (total magnification, $\mathrm{x} 50$ in A, C and D, x100 in B and x200 in the inset of B). 


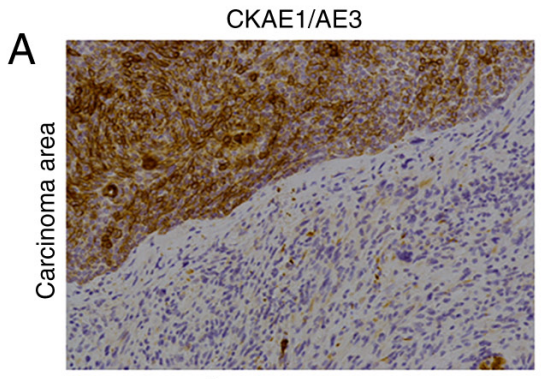

Sarcoma area

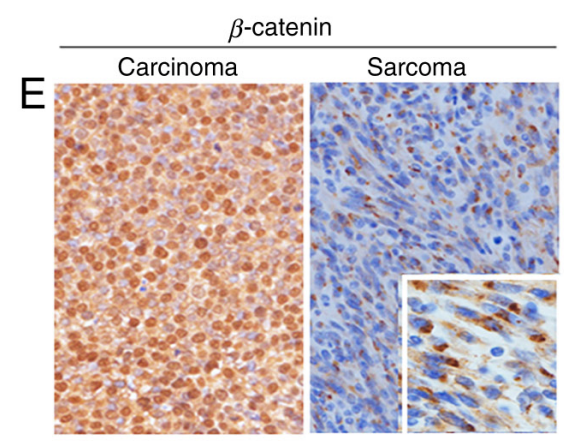

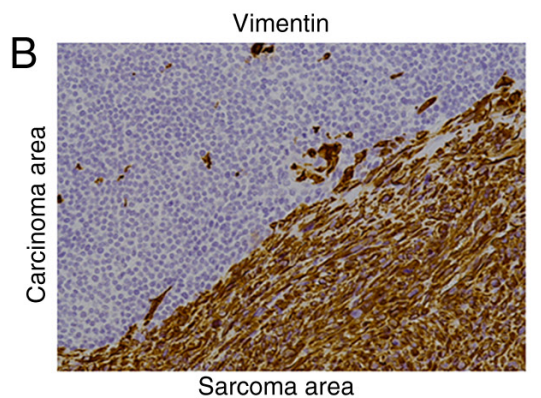

P53

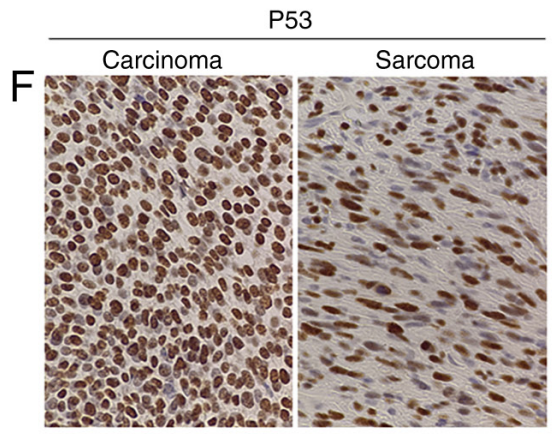

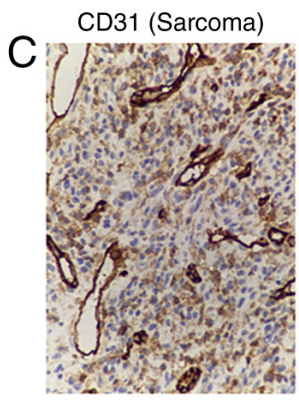

$\alpha-S M A(S a r c o m a)$
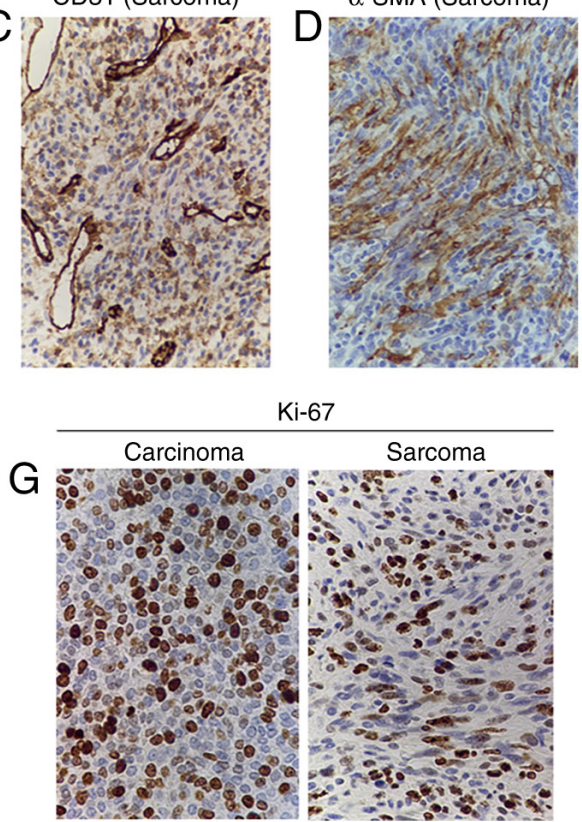

Figure 4. Immunohistochemical staining of the tumor. Representative images of immunohistochemical staining for (A) CK AE1/AE3, (B) Vimentin, (C) CD31, (D) $\alpha$-SMA, (E) $\beta$-catenin, (F) P53 and (G) Ki-67 in the tumor are presented. CK AE1/AE3 was positive in the basaloid cells. A small number of cells were weakly-moderately positive and most of the cells were negative for CK AE1/AE3 in the spindle cell area. The spindle cell area was positive for vimentin, but only a small number of cells in the epithelial lesion were positive for vimentin. CD31 was partially weakly-moderately positive in the spindle cell area. In the small area of the spindle cells, $\alpha$-SMA was positive. $\beta$-catenin was positive in the nuclei and cytoplasm of the basaloid cells and positive in the cytoplasm of certain spindle cells. Numerous P53-positive cells and Ki-67-positive cells were observed among the basaloid cells and the spindle cells (total magnification, $\mathrm{x} 200$ in A-G and $\mathrm{x} 500$ in the inset of E). SMA, smooth muscle actin; CK, cytokeratin.

There were no physical findings suggesting the recurrence and/or metastasis of the tumor. When the patient died, there was no tumor at the resected site. Therefore, it was suggested that the patient did not experience any recurrence or develop any metastatic lesion until his death.

\section{Discussion}

The present study reported on a case of pilomatrical carcinosarcoma of the left auricle in a 100-year-old male patient.

A total of 10 cases of pilomatrical carcinosarcoma, including the present case, have been reported (Tables I and II). Of these, 6 patients were male and four were female. The male-to-female ratio was 3:2. The age of the patients at the time-point of diagnosis ranged from 9 to 100 years and their mean and median ages were 65.7 and 75.5 years, respectively. These results may infer that pilomatrical carcinosarcoma typically develops in elderly males. The results are contrary to pilomatricoma, since the latter usually develops in young individuals and is predominantly observed in females (6). However, due to the small number of patients with pilomatrical carcinosarcoma, further analysis requires to be performed after the accumulation of cases.

Among the 10 known cases of pilomatrical carcinosarcoma, there was one case of distal metastasis to the lungs and one of local recurrence $(11,12)$. In the remaining eight cases, including the present case, neither metastasis nor recurrence has been reported. Regarding therapy in the case of recurrence, tumor resection, lymph node dissection, radiotherapy and chemotherapy were performed (12). In the case of pulmonary metastasis, resection of the original tumor, lymph node dissection and radiotherapy were performed initially (11). Subsequently, pulmonary metastasis of the tumor was detected; hence, resection of the metastatic lesions in the lung was performed (11). In the present case, resection of the tumor without radiation or chemotherapy was performed as the patient was very old.

Regarding the epithelial lesions of the 10 pilomatrical carcinosarcoma cases, two cases were benign pilomatricoma, whereas the remaining eight cases were carcinomas (Table I). Specifically, six cases were pilomatrical carcinoma, one case was pilomatrical carcinoma with basal cell carcinoma and the remaining case was pilomatrical carcinoma with squamous cell carcinoma $(10,13)$. In the sarcomatous lesion, atypical spindle cells or pleomorphic cells were observed. Of the 10 cases, 9 had atypical spindle cells and one had pleomorphic cells, suggesting that atypical spindle cells mainly grow in the sarcomatous lesions in pilomatrical carcinosarcomas. In the present case, the ratio of the epithelial to sarcomatous lesions was 2:3. Only for one out of the previously reported nine cases, this ratio was determined to be 1:1 (5). The spindle cells in Case 5 strongly but focally expressed CK AE1/AE3 and CAM 5.2 (6). The spindle cells of Case 1 also expressed an epithelial marker, CAM 5.2, but were negative for high-molecular-weight keratin and EMA. The sarcomatous areas in Cases 4 and 6 were negative for CK AE1/AE3 and CK 5/6 (5,7). The sarcomatous areas in Cases 9 and 10 were sparsely positive for $\mathrm{CK}$ AE1/AE3 but negative for CK 5/6 and EMA (9). In Cases 2, 3,7 and 8 , epithelial markers in the sarcomatous lesions were not reported $(8,10,12,13)$. The sarcomatous areas were positive for vimentin in Cases 1-4, 9 and 10. There was no mention of immunohistochemical detection of vimentin for Cases 5-8. 
Table I. Literature review and present case of pilomatrical carcinosarcoma.

\begin{tabular}{|c|c|c|c|c|c|c|c|c|c|c|}
\hline \multirow{2}{*}{$\begin{array}{l}\text { First } \\
\text { author } \\
\text { (year) }\end{array}$} & \multirow[b]{2}{*}{$\begin{array}{c}\text { Case } \\
\text { no. }\end{array}$} & \multirow[b]{2}{*}{$\begin{array}{l}\text { Age, } \\
\text { years }\end{array}$} & \multirow[b]{2}{*}{ Sex } & \multirow{2}{*}{$\begin{array}{l}\text { Site of } \\
\text { original } \\
\text { tumor }\end{array}$} & \multirow[b]{2}{*}{$\begin{array}{l}\text { Size }^{\mathrm{a}} \\
\mathrm{mm}\end{array}$} & \multicolumn{2}{|c|}{ Histology } & \multirow[b]{2}{*}{ Treatment } & \multirow[b]{2}{*}{$\begin{array}{l}\text { Prognosis } \\
\text { (OP) }\end{array}$} & \multirow[b]{2}{*}{ (Refs.) } \\
\hline & & & & & & $\begin{array}{l}\text { Epithelial } \\
\text { lesion }\end{array}$ & Sarcoma & & & \\
\hline Hanly (1994) & 1 & 36 & M & Cheek & $40 \times 40$ & P (benign) & MFH & $\mathrm{R}+\mathrm{Ly}+\mathrm{Ra}$ & $\mathrm{PM}^{\mathrm{b}}$ & $(11)$ \\
\hline Scholl (2010) & 2 & 23 & $\mathrm{M}$ & Preauricular & ND & $\mathrm{P}$ (benign) & $\begin{array}{c}\text { ND } \\
\text { (suggesting } \\
\text { fibrosarcoma) }\end{array}$ & $\mathrm{R}$ & Recurrence $^{c}$ & (12) \\
\hline Clark (2017) & 3 & 77 & $\mathrm{M}$ & Cheek & 50 & $\mathrm{PC}, \mathrm{BCC}$ & USCS & $\mathrm{R}$ & $\begin{array}{c}\text { NRM } \\
\text { (2 months) }\end{array}$ & (10) \\
\hline $\begin{array}{l}\text { Suyama, } \\
(2017)\end{array}$ & 4 & 73 & M & Cheek & $20 \times 20$ & $\mathrm{PC}$ & ND & $\mathrm{R}$ & $\begin{array}{c}\text { NRM } \\
\text { (8 months) }\end{array}$ & (5) \\
\hline $\begin{array}{l}\text { Fernandez- } \\
\text { Flires, (2018) }\end{array}$ & 5 & 78 & $\mathrm{M}$ & Hand & 6 & $\mathrm{PC}$ & ND & $\mathrm{R}$ & $\begin{array}{c}\text { NRM } \\
\text { (8 months) }\end{array}$ & (6) \\
\hline Leecy, (2018) & 6 & 87 & $\mathrm{~F}$ & Hand & 16 & $\mathrm{PC}$ & US & $\mathrm{R}$ & $\begin{array}{c}\text { NRM } \\
\text { (6 months) }\end{array}$ & (7) \\
\hline Mori (2019) & 7 & 100 & $\mathrm{~F}$ & Temple & $15 \times 12$ & $\mathrm{PC}$ & US & $\mathrm{R}$ & ND & (8) \\
\hline Gates, (2020) & 8 & 0 & $\mathrm{~F}$ & Neck & $48 \times 40$ & $\mathrm{PC}$ & ND & $\mathrm{R}$ & ND & (13) \\
\hline $\begin{array}{l}\text { Luong, } \\
(2020)\end{array}$ & 9 & 74 & $\mathrm{~F}$ & $\begin{array}{l}\text { Posterior } \\
\text { scalp }\end{array}$ & 25 & $\mathrm{PC}, \mathrm{SCC}$ & UPS & $\mathrm{R}$ & $\begin{array}{c}\text { NRM } \\
\text { (45 months) }\end{array}$ & (9) \\
\hline Present case & 10 & 100 & $\mathrm{M}$ & Auricle & $45 \times 30$ & $\mathrm{PC}$ & USCS & $\mathrm{R}$ & $\begin{array}{c}\text { NRM } \\
\text { (2.5 months) }\end{array}$ & - \\
\hline
\end{tabular}

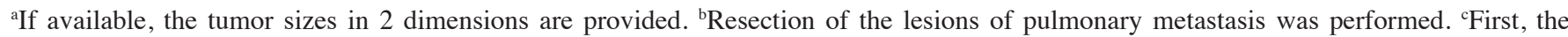
resected tumor was diagnosed as P. Third-time recurrent lesions were diagnosed as pilomatrical carcinosarcoma. The third recurrent lesion and regional lymph nodes were resected, and adjuvant chemotherapy and radiation were performed after the operation. After the third recurrent lesion was resected, the tumor did not recur. BCC, basal cell carcinoma; F, female; Ly, lymph node dissection; M, male; MFH, malignant fibrous histiocytoma; ND, not described; NRM, no recurrence or metastasis; OP, observation period; P, pilomatricoma; PC, pilomatrical carcinoma; PM, pulmonary metastasis; R, resection of the tumor; Ra, postoperative radiation; UPS, undifferentiated pleomorphic sarcoma; US, undifferentiated sarcoma; USCS, undifferentiated spindle cell sarcoma.

In the present case, most of the atypical spindle cells were negative for CK AE1/AE3 but positive for vimentin. A large amount of P53-positive and Ki-67-positive cells were observed. Therefore, the spindle cell area of the tumor was diagnosed as a malignant mesenchymal tumor (sarcoma). Staining for CD31 was partially weakly-moderately positive and CD34 was completely negative in the spindle cell area. On the basis of the findings of negative CD34 and severely atypical spindle cells, vascular tumor and solitary fibrous tumor were unlikely diagnoses in the present case. Negativity for CD56, synaptophysin and chromogranin A suggested that neuroendocrine tumors were improbable, whereas negativity for desmin and a small number of cells positive for $\alpha$-SMA suggested that myogenic tumors were also unlikely. Negativity for S100 suggested that the tumor was not neural. Hence, the spindle cell area was diagnosed as undifferentiated spindle cell sarcoma.

Although $\alpha$-SMA was expressed in the sarcomatous area, suggesting differentiation to smooth muscle in Case 7, it was diagnosed as undifferentiated sarcoma (8). The sarcomatous areas of other pilomatrical carcinosarcomas did not express specific differentiation markers, suggesting that these were undifferentiated sarcomas. It is noteworthy that most sarcomatous areas were undifferentiated sarcomas in the cases of pilomatrical carcinosarcoma.
It has been reported that $\beta$-catenin is a useful marker that may be utilized to establish the diagnosis of pilomatricoma and pilomatrical carcinoma (4). Expression of $\beta$-catenin was examined in six of the 10 pilomatrical carcinosarcoma cases. In these cases, both the epithelioid and sarcomatous areas expressed $\beta$-catenin in the cytoplasm. Certain cells also expressed $\beta$-catenin in the nucleus. These results suggested an association of $\beta$-catenin expression in the cytoplasm and/or nucleus with pilomatrical tumors. It has been reported that the expression of $\beta$-catenin in pilomatricoma and pilomatrical carcinoma was able to be induced by mutations in exon 3 of CTNNB1, suggesting that these mutations may be contributory to pilomatrical tumors (4). However, a study by Suyama et al (5) indicated no mutation in exon 3 of CTNNB1 and Luong et al (9) also demonstrated no mutation in exons 3,4 and 5 of the CTNNB1 gene in their case of pilomatrical carcinosarcoma. Further examination is required to clarify the role of abnormal expression of $\beta$-catenin in pilomatrical carcinosarcomas.

There are several theories regarding the development of carcinosarcoma: A collision of two independent tumors, development from a common precursor to carcinoma and sarcoma, or pre-existence of carcinoma followed by mesenchymal transition $(10,14,15)$. Leecy et al $(7)$ performed a 
Table II. Immunohistochemistry of epithelial and sarcomatous areas in pilomatrical carcinosarcoma.

\begin{tabular}{|c|c|c|c|c|}
\hline $\begin{array}{l}\text { First author } \\
\text { (year) }\end{array}$ & $\begin{array}{c}\text { Case } \\
\text { no. }\end{array}$ & Epithelial area & Sarcomatous area & (Refs.) \\
\hline Hanly (1994) & 1 & $\begin{array}{l}\text { HMW CK (+), EMA (-), CEA (-), } \\
\text { actin (-), chromogranin (-), NSE (-), } \\
\text { HMB45 (-), ulex (-), } \alpha_{1} \text {-antitrypsin }(-), \\
\text { S100 (-), vimentin (-), CAM5.2 (-) }\end{array}$ & $\begin{array}{l}\text { Vimentin (+), CAM5.2+, HMW CK (-), } \\
\text { EMA (-), CEA (-), actin (-), } \\
\text { chromogranin }(-), \operatorname{HMB} 45(-), \text { ulex }(-), \\
\text { NSE (-), } \alpha_{1} \text {-antitrypsin }(-), \text { S100 (-) }\end{array}$ & (11) \\
\hline Scholl (2010) & 2 & CK AE1/AE3 (+) & Factor XIIIa $(+)$, vimentin $(+)$ & $(12)$ \\
\hline Clark, (2017) & 3 & BerEP4 (+), CK5/6 (+) & Vimentin (+) & $(10)$ \\
\hline Suyama (2017) & 4 & $\begin{array}{l}\text { CK AE1/AE3 (+), CK5/6 (+), EMA (+), } \\
\text { CEA (-), CAM5.2 (-), vimentin }(-), \\
\alpha-S M A ~(-), \text { desmin }(-), \text { CD31 (-), } \\
\text { CD34 (-), NSE }(-), \text { S100 (-), Ki-67 } \\
\text { labeling index } 40 \%, \beta \text {-catenin }(+C y, N)\end{array}$ & $\begin{array}{l}\text { Vimentin (+), } \alpha-\operatorname{SMA}(+), \text { NSE } \\
\text { (partially+), CK AE1/AE3 (-), CEA (-), } \\
\text { CK5/6 (-), CAM5.2 (-), desmin (-), } \\
\text { CD31 (-), CD34 (-), S100 (-), Ki-67 } \\
\text { labeling index 20\%, } \beta \text {-catenin } \\
\text { (partially+N) }\end{array}$ & $(5)$ \\
\hline $\begin{array}{l}\text { Fernandez-Flires } \\
\text { (2018) }\end{array}$ & 5 & $\begin{array}{l}\text { CK AE1/AE3 (+), EMA (+), CK5/6 (+), } \\
\text { CAM5.2 (+), CK7 (-), CK20 (-), } \\
\text { S100 (-), TTF-1 (-), BerEP4 (-), } \\
\text { CD34 (-), } \beta \text {-catenin }(+C y)\end{array}$ & $\begin{array}{l}\text { CK AE1/AE3 (focal+), CAM5.2 } \\
\text { (focal+), CK7 (-), CK20 (-), S100 (-), } \\
\text { TTF-1 (-), BerEP4 (-), CD34(-), } \\
\beta \text {-catenin (+Cy) }\end{array}$ & (6) \\
\hline Leecy (2018) & 6 & $\begin{array}{l}\text { CK AE1/AE3 (+), CK7 (-), CK20 (-), } \\
\text { CAM5.2 (-), BerEP4 (-), CD10 (-), } \\
\text { P63 (+), P53 (+), } \beta \text {-catenin (+Cy), } \\
\text { MIB-1 labeling index } 20 \%\end{array}$ & $\begin{array}{l}\text { CK AE1/AE3 (-), CK5/6 (-), CK7 (-), } \\
\text { CK20 (-), CK[MNF116] (-), Desmin (-), } \\
\text { CD10 (+), P53 (+), Sox10 (-), } \beta \text {-catenin } \\
\text { (+Cy), MIB-1 labeling index 5\% }\end{array}$ & (7) \\
\hline Mori (2019) & 7 & CK AE1/AE3+, $\beta$-catenin $(+\mathrm{Cy}, \mathrm{N})$ & $\alpha$-SMA+, $\beta$-catenin $(+\mathrm{Cy}, \mathrm{N})$ & (8) \\
\hline Gates (2020) & 8 & ND & ND & $(13)$ \\
\hline Luong (2020) & 9 & $\begin{array}{l}\text { CK AE1/AE3 (+), CK5/6 (+), P40 (+), } \\
\text { P16 (+), P63 (+), P53, vimentin (-), } \\
\text { SMA (-), CD34 (-), TTF-1 (-), PSA (-), } \\
\beta \text {-catenin }(+C y, N)\end{array}$ & $\begin{array}{l}\text { CK AE1/AE3 (scattered+), CK5/6 (-), } \\
\text { P40 (-), P53 (+), CD34 (-), vimentin }(+), \\
\text { SMA (focal+), } \beta \text {-catenin }(+\mathrm{Cy}, \mathrm{N})\end{array}$ & (9) \\
\hline Present case & 10 & $\begin{array}{l}\text { CK AE1/AE3 (+), CK5/6 (+), P40 (+), } \\
\text { EMA (+), S100 (-), vimentin (mostly } \\
\text { negative, few positive cells), CD31 (-), } \\
\text { CD56 (-), chromogranin A (-), } \\
\text { synaptophysin (-), desmin (-), CA9 (-), } \\
\alpha-S M A(-), \beta-\text { catenin }(+C y, N), \text { Ki-67 } \\
\text { labeling index } 36.4 \%\end{array}$ & $\begin{array}{l}\text { CK AE1/AE3 (mostly negative, few } \\
\text { positive cells), CK5/6 (-), P40 (-), } \\
\text { EMA (-), S100 (-), vimentin (+), CD31 } \\
\text { (focally moderate-weak+), CD56 (-), } \\
\text { chromogranin A (-), synaptophysin (-), } \\
\text { desmin (-), CA9 (-), } \alpha \text {-SMA (focally+), } \\
\beta \text {-catenin (+Cy), Ki-67 labeling index } \\
35.8 \%\end{array}$ & - \\
\hline
\end{tabular}

Cy, cytoplasm; CA9, carbonic anhydrase 9; CEA, carcinoembryonic antigen; CK, cytokeratin; EMA, epithelial membrane antigen; HMW, high molecular weight; M, membrane; N, nucleus; NSE, neuron-specific enolase; PSA, prostate-specific antigen; SMA, smooth muscle actin; TTF-1, thyroid transcription factor- $1 ;+\mathrm{Cy}$, positive in the cytoplasm; $+\mathrm{Cy}, \mathrm{N}$, positive in the cytoplasm and nucleus; $+\mathrm{N}$, positive in the nucleus

comparative genomic hybridization analysis of both carcinoma and sarcoma components in pilomatrical carcinosarcoma wherein a common clonal origin was determined, similar to the abnormal expression of $\beta$-catenin.

In six out of the previously reported nine cases of pilomatrical carcinosarcomas, boundaries of the carcinomas and sarcomas were described $(5,7-9,11,12)$. In the six cases along with the present case, the epithelial and sarcomatous areas closely intermingled and gradually transitioned. The morphological, immunohistochemical and genetic examination results suggested two possibilities: Derivation of both components from the same progenitor cells and transition of the epithelial tumor into a mesenchymal tumor through epithelial-mesenchymal transition (5). In Case 5, CK AE1/AE3 and CAM 5.2 were expressed focally and strongly, suggesting that the sarcomatous area was able to undergo epithelial-mesenchymal transition (6).

In conclusion, the present study reported a rare case of pilomatrical carcinosarcoma that developed in a 100-year-old male patient. Careful observation of histological morphology and immunohistochemical staining is considered important in establishing the diagnosis of pilomatrical carcinosarcoma.

\section{Acknowledgements}

The authors thank Ms. Hitomi Ogaki, Mr. Katsuya Nagaoka and Mr. Hiroaki Takenaka (Department of Laboratory, Toyooka Hospital, Toyooka, Japan) for the preparation of histopathological specimen sections and their staining. 


\section{Funding}

No funding was received.

\section{Availability of data and materials}

The datasets used and/or analyzed during the current study are available from the corresponding author upon reasonable request.

\section{Authors' contributions}

KS, YA, MT and SI designed the study. KS, YA, TT and HA analyzed and interpreted the patient data. KS, YA and SI were major contributors in writing the manuscript. KS, YA, MT and SI performed the histological examination of the tumor and performed histological diagnosis. All authors except for Professor SI, who died in June 2021, read and agreed to the final version of the study. KS and YA checked and approved the authenticity of the raw data.

\section{Ethics approval and consent to participate}

The Ethics Committee of Toyooka Hospital (Toyooka, Japan) approved the present study.

\section{Patient consent for publication}

The family of the patient provided written informed consent for the patient information and images to be published.

\section{Competing interests}

The authors declare that they have no competing interests.

\section{References}

1. Jones C, Twoon M, Ho W, Portelli M, Robertson B and Anderson W: Pilomatrix carcinoma: 12-year experience and review of the literature. J Cutan Pathol 45: 33-38, 2018.
2. Nogal P, Bartkowiak E, Iwanik K and Wierzbicka M: Common sense and tumor treatment. A case of pilomatrical carcinoma in a 21-year-old patient with surprisingly rapid tumor progression. Oral Oncol 112: 105007, 2021.

3. Xing L, Marzolf SA, Vandergriff T and Nijhawan RI: Facial pilomatrix carcinomas treated with Mohs micrographic surgery. JAAD Case Rep 4: 253-255, 2018.

4. Lazar AJ, Calonje E, Grayson W, Dei Tos AP, Mihm MC Jr, Redston $\mathrm{M}$ and McKee PH: Pilomatrix carcinomas contain mutations in CTNNB1, the gene encoding beta-catenin. J Cutan Pathol 32: 148-157, 2005.

5. Suyama T, Momose S, Yokoyama M, Kikuchi J, Izaki S, Arai E and Tamaru J: Pilomatrical carcinosarcoma of the cheek: Immunohistochemical and molecular analysis of beta-catenin. Pathol Int 67: 324-326, 2017.

6. Fernandez-Flires A and Cassarino DS: Sarcomatoid pilomatrix carcinoma. J Cutan Pathol 45: 508-514, 2018.

7. Leecy T, Ardakani NM, Harvey NT and Wood BA: Pilomatrical carcinosarcoma: Report of a case with comparative genomic hybridization analysis. Pathology 50: 571-573, 2018.

8. Mori D: Pilomatrical carcinosarcoma of the temple: A case report. J Cutan Pathol 46: 267-270, 2019.

9. Luong TMH, Akazawa Y, Mussazhanova Z, Matsuda K, Ueki N, Miura S, Hara T, Yokoyama $\mathrm{H}$ and Nakashima M: Cutaneous pilomatrical carcinosarcoma: A case report with molecular analysis and literature review. Diagn Pathol 15: 7, 2020.

10. Clark JJ, Bowen AR, Bowen GM, Hyngstrom JR, Hadley ML, Duffy K, Florell SR and Wada DA: Cutaneous carcinosarcoma: A series of six cases and a review of the literature. J Cutan Pathol 44: 34-44, 2017.

11. Hanly MG, Allsbrook WC, Pantazis CG, Lane R, Porubsky ES and Mann ES: Pilomatrical carcinosarcoma of the cheek with subsequent pulmonary metastases. A case report. Am J Dermatopathol 16: 196-200, 1994.

12. Scholl P, Snyder N, Patt D and Talbott B: Pilomatrical carcinosarcoma. Otolaryngol Head Neck Surg 143 (Suppl 3): S36-S37, 2010.

13. Gates GA, Nguyen J and Binder SW: Rare case report of pilomatrical carcinosarcoma in a pediatric patient. Am J Dermatopathol 42: 208-210, 2020.

14. Zbacnik AP, Rawal A, Lee B, Werling R, Knapp D and Mesa H: Cutaneous basal cell carcinomsarcoma: Case report and literature review. J Cutaneous Pathol 42: 903-910, 2015.

15. Bigby SM, Charlton A, Miller MY, Zwi LJ and Oliver GF: Biphasic sarcomatoid basal cell carcinoma (carcinosarcoma): Four cases with immunohistochemistry and review of the literature. J Cutan Pathol 32: 141-147, 2005.

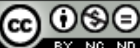

This work is licensed under a Creative Commons Attribution-NonCommercial-NoDerivatives 4.0 International (CC BY-NC-ND 4.0) License. 